\title{
Exploring the Factors Influencing Students in Enrolling Tourism and Hospitality Management Colleges in Jordan: A Case Study in Aqaba Economic Zone
}

\author{
Dr. Omar Abedalla Alananzeh \\ Department of Hotel Management \\ Faculty of Tourism and Hospitality, The University of Jordan \\ E-mail: omarananzeh@yahoo.com
}

Received: March 7, 2014 Accepted: March 18, 2014 Published: April 1, 2014

doi:10.5296/jmr.v6i2.5257

URL: http://dx.doi.org/10.5296/jmr.v6i2.5257

\begin{abstract}
The importance of enrolling students in tourism studies is critical. This study aimed to explore the factors that influence male and female students in joining hotel management department and Food and Beverage service department in Jordan. Two universities were choosing among the area of study. Using systematic random sample technique to select students from both universities, results showed that social and cultural factors influence the choice of specialization hotel management or food \& beverage service, with the exception of some things like the father's career (currently working in tourism or indirectly), and mother's career (working in tourism or indirectly), the different cultures of tourists, as well as friends do not influence the selection of the Faculty of tourism and hospitality.
\end{abstract}

Keywords: Soci-cltural factors, Personal factors, Hotels, Food and Beverage, Jordan. 


\section{Introduction:}

Jordan, as a small country, lies in the heart of the Middle East. It is rich with wide range of tourist attractions. For instance, the Red Rose City (Petra) was elected as one of the new Seven Wonders of the World in 2007, Jerash, Baptism Site, Um Qais, Philadelphia, the Dead Sea and many castles and desert palaces spotted over the land of Jordan as well as its unparalleled natural locations, observing cultural and religious sites and traditions. Moreover, Jordanian hospitality is well-known by tourists (Chiu \& Ananzeh, 2012, Reid \& Schwab 2006, Schneider \& Sonmez, 1999). Kelly (1998) stated that tourists consider Jordan to be a safe destination and that Jordanians are friendly, hospitable, and generous hosts. In addition to its historical sites, Jordan offers health tourism, leisure tourism, education tourism, adventure, scuba diving, cultural tourism, shopping tourism, and religious tourism. Its security and stability in the Middle East attract tourists as one of the safest destinations for tourism. The contribution of tourism is more important for the economy of Jordan due to the limited resources in water and other mineral resources compared to the neighbouring countries. Rosenberg and Choufany (2009) proclaimed that the revenue from tourism in 2010 accounted for 14 percent of Jordan's Gross Domestic Product (GDP). Thus, to enhance and improve tourism sector, Jordan Tourism Board (JTB) developed the National Tourism Strategy (NTS) 2004-2010 which aimed to develop a sustainable tourism economy with a partnership among government, the private sector and the civil societies. One of the goals of this national strategy is to create more than 51,000 jobs. As a result, the direct employment in tourism industry had increased by almost $85 \%$ including $10 \%$ for female participation. Then, this strategy was extended to 2011-2015 which aimed to increase tourism receipts to JD 4.2 billion in 2015, to create additional 25,000 jobs over the period, and to increase the female participation in the tourism sector by $15 \%$ (JTB, 2011).

\section{Literature review}

The countries of the world have realized the fact that tourism is one of the most important industry and a major sources of employment. According to International Labour Organization's statistics (ILO) in 2013, tourism industry provided more than 225 million jobs all over the world in 2010 and expected to provide 296 million jobs by 2019. The Ministry of Tourism and Antiquities in Jordan (MOTA) has announced that around 46666 employees are working directly in tourism sector, 16960 are working in hotels. 14861 are Jordanians employees where 2099 are foreigners. The male employees constitute the most labour force in hotel sector; they are 15558 while 1402 are female employees. Meanwhile, 19407 are working in restaurants, 13055 are Jordanians and 6352 are foreigners. The majority of restaurant employees are males 17788 and 1619 are females (MOTA, 2013). The statistics also shows that Aqaba comes second as a tourist destination after the capital Amman in the number of hotels. There are 41 classified hotels, 2660 employees are working in these hotels, and among them 1822 are Jordanian male employees and 59 Jordanian female employees, while 692 are non-Jordanian male employees and 87 non-Jordanian female employees. The number of Jordanians working in tourism sector has increased but tourism sector still depends on foreign employees to run the service. Al Azzam and Khaleefah (2012) conducted a study to explore the reasons behind the employment of foreign administrations to run hotels 
in Aqaba. The results of their study revealed that there were no significant differences between local administrations and foreign administrations regarding their behaviour, skills, and efficiency.

Thus, it is vital to start from the beginning, to diagnosis the problem in order to find the healing for this case in Jordan. The answer should starts from undergraduate students (male and female) who are the labour force of today and the future. Poylu (2008) explored the problem related to tourism education in Turkey and advised that research should start from university level students and not from vocational schools who are not physically and mentally mature for this field. Therefore, A few studies have searched tourism students such as (Roney \& Oztin, (2007) examined career perception of undergraduate tourism students, Lee and Chatfield (2011) studied the factors affecting choice of college for hotel students, Lu and Adler (2009) discussed the expectation of hospitality and tourism management students from their future career, Davis (2009) conducted a study to examine American students' perceptions of the tourism industry in United State universities and the factors that influence them to pursue a tourism career path.

Roney and Oztin (2007) examined the career perceptions of undergraduate tourism student in Turkey, their results showed that in spite of the sophisticated human resource policy and practices in many tourism businesses, students have the willingness to study tourism and to work in tourism industry after graduation.

Gurel, Altinay and Daniele (2009) pointed out to the influence of traditional tourism and hospitality management education on students in developing countries, the influence of parents on their intention to continue their parents business or start a new one, and the influence of their socio- cultural background such as family background, education, and national culture on their behaviour and intention to start a new business in tourism. Apparently, searching previous research revealed that focusing on Jordanian tourism students regarding factors influencing their enrollment in tourism and hospitality colleges so far has not been searched.

Abu Alhija (2011) explained the soci-cultural conflict between the host community and the tourists, he pointed out that $92 \%$ of the population in Jordan are Muslims, despite that Islam orders his followers to respect other religions, cultures, and races, but several behaviors of tourists that go against Islam principles such as eating pork meat and drinking liqueur, the way tourists dress, especially uncovering their delicate part of their bodies evoke some kinds of hostility towards tourists or prevent slices of people to deal with them or works in facilities that offer services to them such as hotels and restaurants. Kelly (1998) searched the potential of developing tourism in Jordan and found that no strong objections have been raised.

He also clarified that women have tendency to work in tourism sector especially in hotels and restaurant due to their religion (to respect other religion) and tradition (to offer hospitality and generosity to their guests). Magableh (2005) stated the factors that prevent women to work in hotels such as habits and traditions of not allowing women to works for long hours especially at night, principles of religion that prohibited serving alcoholic, and the main factor is women don't have the qualifications and education required. 
Chugh (2012) pointed out that tourism industry cannot be visualized without women participating actively in the growth of the industry. According to the reports of International Labour Office (2007), women work in tourism accounted for $46 \%$ labour force in tourism globally. Nevertheless, figures shows that females working in hotels and food and beverage services in Jordan are below expected levels.

The annual report of MOTA reveal that the participation of women in tourism sector is increasing even it is still below the demanded level. Reports point out that the level of education, self-confidence, and improvement of work conditions attract women to tourism industry.

\section{Justification for the Study}

Due to the above figure and the very limited research that has been dealt with such topic in other countries rather than in Jordan, this study was conducted to explore the factors that influence Jordanian students (male and female ) in enrolling tourism and hospitality colleges particularly in the majors Hotel Management Department and Food and Beverage Service Department. The specific objects of this study were (1) to explore the factors that influence students in enrolling tourism and hospitality management, (2) to find out students' perception and expectations in enrolling tourism and hospitality management specially to shed more lights on female students' perception and expectation, and (3) to compare the influence of these factors on female and male students.

\section{Methods}

\subsection{Study Site}

Two universities, the University of Jordan and Al-Balqa' Applied University College, were chosen for the study because these are the only universities in the site of the study. Tourism and Hospitality College in the University of Jordan has three departments; Tourism and Travel Department, Hotel Management Department, and Food and Beverage Service Department and students will get their Bachelor degree after four years of studying. Student of Tourism and travel department were excluded because the study is focusing on hotel and food and beverage. While Al-Balqa' Applied University College has one department for hotel management but it has two programs, the first one is two years of studying and students graduate will hold Diploma certificate in Hotel Management and four years program granting students Bachelor degree in hotel management, but it teaches students food and beverage services among their programs.

\subsection{Study Hypotheses:}

H1: There is no difference between the influence of soci-cultural factors on male and female students in enrolling Hotel management and food and beverage management in tourism and hospitality colleges in Jordan.

H2: There is no difference between the influence of personal factors on male and female students in enrolling Hotel management and food and beverage management in tourism and hospitality colleges in Jordan. 
H3: Socio-cultural factors positively influence students in enrolling tourism and hospitality colleges in Jordan.

H4: Personal factors positively influence students in enrolling tourism and hospitality colleges in Jordan.

\subsection{Research Design, Sample, and Procedure}

Correlational design was utilized by using quantitative approach; a personal survey method through a structured questionnaire was administered to explore the factors that affecting students in enrolling hotel management department and food and beverage service department. More specifically, this study was conducted to determine the relationships between personal factors and socio-cultural factors and enrolling tourism and Hospitality College, also, to show if there are differences on the effect of these factors between male and female students. The study used self-administered questionnaire to collect data from the respondents.

The study was conducting between December 2013 and February 2014. The questionnaire was personally administered to respondents during their classrooms. Subjects were selected using simple random sampling techniques. A list of currently enrolled undergraduate students was taken from the registration department in each university. T-test, ANOVA, and simple linear regression were employed to test the hypothesis.

\subsection{Measurement}

The questionnaire was consisted of three sections. The first section was designed to explore the effect of personal factor (perceptions and expectations) on enrolling tourism studies (hotel manage and food and beverage service) in Jordan. Eleven items, a 5-point Likert scale ranging from 1 (strongly disagree) to 5 (strongly agree) were chosen. In the second section, respondents were asked to identify the effect of socio-cultural factor on their enrolling tourism studies (hotel manage and food and beverage service) in Jordan. Fifteen items, a 5-point Likert scale ranging from 1 (strongly disagree) to 5 (strongly agree) were chosen. The items in this study were chosen after revising previous studies (Aksu \& Koksal, 2005; Davis, 2009; Lu \& Alder, 2009; Roney \& Oztin. 2007). The third section was designed to get more information about students' sociodemographic characteristics of the respondents such as gender, study grade, intention to work, and previous experience and education.

\section{Data Analyses}

\subsection{Reliability Analysis}

The scale reliability was checked by Cronbach's alpha Reliability test. From table 1 it is evident that:

- The Cronbach's alpha value of the dimension of sociocultural factors has reached 0.78

- The Cronbach's alpha value of the dimension of personal factors has reached 0.81

- $\quad$ The Cronbach’s alpha value of all items has reached 0.82 
Since all these values are greater than 0.60 , the study is reliable.

Table 1. Reliability statistics for the variables of the study

\begin{tabular}{|l|l|}
\hline Dimension & Cronbach's alpha \\
\hline Socio cultural factors & 0.78 \\
\hline Personal factors & 0.81 \\
\hline Total & 0.82 \\
\hline
\end{tabular}

Description of the Personal and functional factors of the respondents

Table 2 illustrates the personal and functional factors of the individuals of the sample of the study as follows:

- Gender

$27.6 \%$ of the sample are males, $36.4 \%$ of the sample are females.

- University

$51 \%$ of the sample was from Al- Balqa' Applied University and $49 \%$ was of student of University of Jordan.

- Department

$68 \%$ of respondents were from hotel management, and $32 \%$ of the sample was of food and beverage service

- Educational level

It is found that $32 \%$ was from second year level, $27 \%$ was from third year level, $24 \%$ from first year level and 19\% from fourth year level.

- Did you finish your secondary study in vocational school?

$58 \%$ of the respondents did not finish their secondary study in a vocational school.

- Did you choose your subject by your own?

It is found that $6 \%$ of the students did not choose their subject of study by their own while $34 \%$ choose it by their own.

- Do you have a previous experience in hospitality or work in the service of food and beverage?

$62 \%$ of the respondents have not any experience in hospitality or work in the service of food and beverage while $38 \%$ of the sample has this experience.

- Are you currently working during your studies in tourism and hospitality?

$81 \%$ of the sample did not work in the field of tourism and hospitality during their University study and $19 \%$ of the sample works in this field. 
- Where do you work?

42.11\% of the sample works in Hotels, $26.32 \%$ of the sample in restaurants field, $10.53 \%$ in field of tourism and travel companies and $5.26 \%$ of the sample in aviation sector and $15.79 \%$ of the sample in other sectors.

- Do you intend to work in your own subject after graduation?

$82 \%$ of students intending to work in their field after graduation, and $6 \%$ did not intend so, while $12 \%$ undecided.

Table 2. Frequencies and percentages of the personal variable of respondents

\begin{tabular}{|c|c|c|c|}
\hline Variable & & Frequency & Percentage \% \\
\hline \multirow[t]{2}{*}{ Gender } & Male & 76 & $76 \%$ \\
\hline & Female & 24 & $24 \%$ \\
\hline \multirow[t]{2}{*}{ University } & University of Jordan-Aqaba & 49 & $49 \%$ \\
\hline & $\begin{array}{l}\text { Al-Balqa Applied University- } \\
\text { Aqaba College }\end{array}$ & 51 & $51 \%$ \\
\hline \multirow[t]{2}{*}{ Department } & Hotel management & 68 & $68 \%$ \\
\hline & Food and beverage service & 32 & $32 \%$ \\
\hline \multirow[t]{4}{*}{ Educational level } & First year level & 27 & $27 \%$ \\
\hline & Second year level & 32 & $32 \%$ \\
\hline & Third year level & 24 & $24 \%$ \\
\hline & Fourth year level & 19 & $19 \%$ \\
\hline \multirow{2}{*}{$\begin{array}{l}\text { Did you finish your secondary } \\
\text { study in vocational school? }\end{array}$} & Yes & 42 & $42 \%$ \\
\hline & No & 58 & $58 \%$ \\
\hline \multirow{2}{*}{$\begin{array}{l}\text { Did you choose your subject by } \\
\text { your own? }\end{array}$} & Yes & 34 & $34 \%$ \\
\hline & No & 66 & $66 \%$ \\
\hline \multirow{2}{*}{$\begin{array}{l}\text { Do you have a previous } \\
\text { experience in hospitality or } \\
\text { work in the service of food and } \\
\text { beverage? }\end{array}$} & Yes & 38 & $38 \%$ \\
\hline & No & 62 & $62 \%$ \\
\hline \multirow{2}{*}{$\begin{array}{l}\text { Are you currently working } \\
\text { during your studies in tourism } \\
\text { and hospitality? }\end{array}$} & Yes & 19 & $19 \%$ \\
\hline & No & 81 & $81 \%$ \\
\hline \multirow[t]{5}{*}{ Where do you work? } & Hotels & 8 & $42.11 \%$ \\
\hline & Restaurants & 5 & $26.32 \%$ \\
\hline & $\begin{array}{l}\text { Tourism and travel } \\
\text { companies }\end{array}$ & 2 & $0.53 \%$ \\
\hline & Aviation & 1 & $5.26 \%$ \\
\hline & Other & 3 & $15.79 \%$ \\
\hline \multirow{3}{*}{$\begin{array}{l}\text { Do you intend to work in your } \\
\text { own subject after graduation? }\end{array}$} & Yes & & \\
\hline & No & 6 & $6 \%$ \\
\hline & Did not decide yet & 12 & $12 \%$ \\
\hline
\end{tabular}




\subsection{Testing and analyzing of hypotheses}

The first hypothesis:

Social and cultural factors affect choosing the specialization subjects: hotel management, food \& beverage service.

Table 3 shows that the arithmetic means of all items except items: 5, 6, 8, 10 is above 3.00 with significance level less than 0.05 which means that it is statistically significant. Henceforth these factors affect choosing the specialization subject.

Item 5 has got an arithmetic average less than 3.00 which mean that it is not statistically significant. This indicates that the profession of the father (currently working in tourism or indirectly) does not affect choosing specialization. Item 6 also has got an arithmetic average less than 3.00. This indicates that the profession of the father profession (working in tourism or indirectly) does not affect schooling.

Item 8 has got an arithmetic average less than 3.00, which mean that different cultures of the tourists have no effect on the choice of specialization.

Item 10 has got an arithmetic average less than 3.00 which mean that friends do not influence selection of the Faculty of tourism and hospitality.

Items together have got an arithmetic average 3.20 with observed significance level of 0.00 , thus the first hypothesis is accepted which means that social and cultural factors influence the choice of specialization subjects: hotel management, food \& beverage service. 
Table 3.Mean, standard deviation, t-value and observed significance level of the dimension of sociocultural factors

\begin{tabular}{|c|l|l|l|l|l|}
\hline No & Item & Mean & S.D & t-value & Sig. \\
\hline 1 & $\begin{array}{l}\text { The effect of father's educational level on } \\
\text { specialization }\end{array}$ & 3.98 & 0.92 & 5.26 & 0.00 \\
\hline 2 & $\begin{array}{l}\text { The effect of mother's educational level on } \\
\text { specialization }\end{array}$ & 3.55 & 0.95 & 4.28 & 0.00 \\
\hline 3 & $\begin{array}{l}\text { Family's member encouragement to choose } \\
\text { a certain subject }\end{array}$ & 3.75 & 1.14 & 3.07 & 0.01 \\
\hline 4 & $\begin{array}{l}\text { The effect of economic income in selecting } \\
\text { specialization }\end{array}$ & 3.18 & 1.10 & 2.72 & 0.02 \\
\hline 5 & $\begin{array}{l}\text { The profession of the father (working } \\
\text { currently in tourism directly or indirectly) }\end{array}$ & 2.59 & 1.21 & -3.86 & 0.00 \\
\hline 6 & $\begin{array}{l}\text { The profession of the mother (working } \\
\text { currently in tourism directly or indirectly) }\end{array}$ & 2.87 & 1.19 & -2.19 & 0.03 \\
\hline 7 & $\begin{array}{l}\text { Prevalent customs and social traditions } \\
\text { effect of choosing a specialization }\end{array}$ & 3.15 & 1.25 & 2.82 & 0.01 \\
\hline 8 & $\begin{array}{l}\text { The effect of different cultures of the } \\
\text { tourists on choosing specialization }\end{array}$ & 2.73 & 1.05 & -1.80 & 0.04 \\
\hline 9 & $\begin{array}{l}\text { The effect of religious teachings on } \\
\text { choosing specialization }\end{array}$ & 3.27 & 1.00 & 3.81 & 0.00 \\
\hline 10 & $\begin{array}{l}\text { The effect of friends on choosing } \\
\text { specialization }\end{array}$ & 2.91 & 1.21 & -0.72 & 0.05 \\
\hline & Total & 3.20 & 0.98 & 3.02 & 0.00 \\
\hline
\end{tabular}

The second hypothesis

There are personal factors that affect my selection of study specialization in either hotel management or food and beverage service.

Table 4 shows that the arithmetic means of all items except items: 23, 24, 25 are above 3.00 with significance level less than 0.05 which means that they are statistically significant. Henceforth these factors affect choosing the specialization subject.

Item 23 has got an arithmetic average less than 3.00 so that it is not statistically significant, which means that there is not any mistake in students' selection of the specialization as a future career. Item 24 has also got an arithmetic mean less than 3.00 which means that the students would work in tourism after graduation.

Although item 5 has got an arithmetic mean less than 3.00 but the observed significance level was greater than 0.05 which means that working in tourism does not enable student to use their skill and creativity. 
Items together have got an arithmetic average 3.41 with observed significance level of 0.00 , thus the second hypothesis is rejected which means that the personal factors influence the choice of specialization subjects: hotel management, food \& beverage service.

Table 4. Arithmetic mean, standard deviation, t-value and observed significance level of the dimension of personal factors

\begin{tabular}{|c|l|r|r|r|r|}
\hline No & Item & Mean & S.D & t-value & \multicolumn{1}{|l|}{ Sig. } \\
\hline 11 & $\begin{array}{l}\text { Meeting new people while working in tourism is } \\
\text { an enjoyable experience }\end{array}$ & 3.73 & 0.91 & 7.86 & 7.86 \\
\hline 12 & Making a good capital by working in tourism & 4.23 & 0.75 & 12.12 & 12.12 \\
\hline 13 & $\begin{array}{l}\text { There are Good career promotion opportunities } \\
\text { in tourism }\end{array}$ & 3.77 & 0.62 & 16.61 & 16.61 \\
\hline 14 & $\begin{array}{l}\text { In General, the advantages of working in the } \\
\text { tourism sector exceed the disadvantages }\end{array}$ & 3.50 & 0.70 & 13.25 & 13.25 \\
\hline 15 & Irregular work hours adversely affect my family & 3.36 & 0.83 & 10.37 & 10.37 \\
\hline 16 & $\begin{array}{l}\text { Work in the tourism sector does not guarantee } \\
\text { me the future }\end{array}$ & 3.18 & 0.83 & 9.90 & 9.90 \\
\hline 17 & $\begin{array}{l}\text { Tourism is a suitable environment for work and } \\
\text { creativity }\end{array}$ & 3.36 & 0.92 & 8.45 & 8.45 \\
\hline 18 & I have practical experience in tourism & 3.27 & 0.75 & 11.03 & 11.03 \\
\hline 19 & I have friends and relatives working in tourism & 3.77 & 0.91 & 8.82 & 8.82 \\
\hline 20 & I'll work in tourism after my graduation & 3.95 & 0.87 & 10.64 & 10.64 \\
\hline 21 & $\begin{array}{l}\text { Working in tourism provides me with travel } \\
\text { opportunities }\end{array}$ & 3.50 & 0.80 & 12.03 & 12.03 \\
\hline 22 & $\begin{array}{l}\text { Working in tourism will find out about the } \\
\text { Customs and traditions of different cultures for } \\
\text { tourists }\end{array}$ & 3.68 & 0.90 & 9.48 & 9.48 \\
\hline 23 & $\begin{array}{l}\text { Working in tourism will help me to find out } \\
\text { about the Customs and traditions of different } \\
\text { cultures of the tourists }\end{array}$ & 2.27 & 0.78 & -2.51 & -2.51 \\
\hline 24 & I will not work in tourism after graduation & 2.45 & 0.96 & -5.79 & -5.79 \\
\hline 25 & $\begin{array}{l}\text { Working in tourism help me to use my skills and } \\
\text { my creations }\end{array}$ & 3.05 & 0.87 & 1.90 & 1.90 \\
\hline & Total & 3.41 & 0.91 & 9.37 & 9.37 \\
\hline
\end{tabular}

The third hypothesis

There are no differences in the impact of social and cultural factors on choosing specialization either hotel management or food \& beverage service attributed to gender variable.

Table 5 shows that the arithmetic mean of the responses of males is higher than 3.27 and is greater than that of the females which is 3.05 , and this difference is statistically significant as 
the observed significance level equals 0.04 henceforth the third hypothesis is rejected, so that there is a difference in the impact of social and cultural factors on choosing specialization either hotel management or food \& beverage service attributed to gender variable in favor of males.

Table 5. the results of differences test attributed Gender

\begin{tabular}{|c|c|c|c|c|}
\hline Dimension & $\begin{array}{l}\text { Males } \\
\text { Arithmetic } \\
\text { average }\end{array}$ & $\begin{array}{l}\text { Females } \\
\text { Arithmetic } \\
\text { average }\end{array}$ & $\begin{array}{l}\text { t-value of } \\
\text { differences }\end{array}$ & $\begin{array}{l}\text { Observed } \\
\text { significance }\end{array}$ \\
\hline $\begin{array}{l}\text { Sociocultural } \\
\text { factors }\end{array}$ & 3.27 & 3.05 & 2.85 & 0.04 \\
\hline Personal factors & 3.40 & 3.44 & 0.72 & 0.65 \\
\hline
\end{tabular}

The fourth hypothesis

There are differences in the extent of the impact of personal factors to choose subject specialization either hotel management or food \& beverage service attributed to gender variable.

Table 5 shows that the arithmetic mean of responses of males is 3.40 which is greater than that of the females which equals 3.05, this difference is not statistically significant as the observed significance level equals 0.65 so that the fourth hypothesis is rejected which means that there is no difference in the impact of personal factors on choosing subject specialization either hotel management or food \& beverage service attributed to gender variable.

\section{Results}

1. There are social and cultural factors influence the choice of specialization hotel management or food \& beverage service, with the exception of some things like the father's career (currently working in tourism or indirectly), and mother's career (working in tourism or indirectly), the different cultures of tourists, as well as friends do not influence the selection of the Faculty of tourism and hospitality.

2. There are personal factors affect the choice of specialization hotel management or food \& beverage service, with the exception that there wasn't an error in students selection of the specialization as a future career, also students will work in tourism after graduation.

3. There is a difference in the impact of social and cultural factors on choosing of specialization hotel management or food \& beverage service due to the variable gender and in favor of males.

4. There are no differences in the impact of personal factors to choose of specialization hotel management or food \& beverage service due to gender. 


\section{References}

Abu Al Haija, A. (2011). Jordan: Tourism and conflict with local communities. Habitat International, 35, 93-100. http://dx.doi.org/10.1016/j.habitatint.2010.04.002

Aksu, A,A., \& Koksal, C, D. (2005). Perceptions and attitudes of tourism students in Turkey. International Journal of Contemporary Hospitality Management, 17, 5,436-447. ISSN: 0959-6119. http://dx.doi.org/10.1108/09596110510604869

Al Azzam and Khaleefah. (2012). Replacing Foreign Staff with Skilled Jordanian Staff in The Hospitality Industry of Four and Five Star Hotels at Aqaba City, Jordan.

Chui, L, K. \& Ananzeh, O, A. (2012). The Role of MICE Destination Attributes on Forming Jordan Touristic Image. Academic Research International, 3(1).

Chugh, S, R. (2012). Empowering Women through Tourism: A Study of Kullu Valley. Asia -Pacific Journal of Innovation in Hospitality and Tourism, 1, 215-227. ISSN: 2289-1471.

Davis (2009). Factor influencing career choice among students enrolled in a four-year tourism administration program. Unpublished doctoral dissertation, Southern Illinois University Carbondale

Gurel, E., Altinay, L., \& Daniele, R. (2010). Tourism students' entrepreneurial intentions. Annals of Tourism Research, 37(3), 646-669. 0160-7383. http://dx.doi.org/10.1016/j.annals.2009.12.003

Kelly, M. (1998). JORDAN|S POTENTIAL TOURISM DEVELOPMENT. Annals of Tourism Research, 25(4), 904_918. 0160-7383. http://dx.doi.org/10.1016/S0160-7383(98)00027-9

Lee, S.J., \& Chatfield, H K. (2011). The analysis of Factors affecting choice of college: A case study of UNLV hotel College students Retrieved from http://scholarworks.umass.edu/cgi/viewcontent.cgi?article=1288\&context=gradconf_hospitali ty

LU, T (YING), \& ADLER, H. (2009). Career Goals and Expectations of Hospitality and Tourism Students in China. Journal of Teaching in Travel \& Tourism, 9, 63-80. ISSN: 1531-3220. http://dx.doi.org/10.1080/15313220903041972

Magableh, Khalid. (2005). Dimensions of participation of Jordanian women working in Jordan's tourism sector. Journal of Yarmouk Research, series of humanities and social sciences. Irbid, Jordan.

Ministry of Tourism and Antiquities. (2013). Jordan Tourism Strategy 2004-2010. Retrieved from http://www.tourism.jo/inside/Strategy.asp.

Ministry of Tourism and Antiquities (MoTA, 2013). Tourism Statistics 2009,issu3,volume 9 . Retrieved from http://www.tourism.jo/GuestBook/Statistics.asp. 


\section{Macrothink}

Journal of Management Research

ISSN 1941-899X 2014, Vol. 6, No. 2

Poylu, Y. (2008). Problems related to approach to tourism education. Retrieved from http://www.bjmer.net/DergiPdfDetay.aspx?ID=70

Reid, M., \& Schwab, W. (2006). Barriers to sustainable development: Jordan's sustainable tourism strategy. Journal of Asian and African Studies, 41(5-6), 439-457. http://dx.doi.org/10.1177/0021909606067408

Roney, S,A. \& Oztin, P. (2007). Career Perceptions of Undergraduate Tourism Students: A Case Study in Turkey. Journal of Hospitality, Leisure, Sport \& Tourism Education, 6(1). ISSN:1473- 8376. http://dx.doi.org/10.3794/johlste.61.118

Rosenberg, P., \& Choufany, H. (2009). Jordan A Vital Tourism Sector. HVS Global Hospitality Services-Dubai. Retrieved from http://www.siyaha.org/v2/documents/365.

Schneider, I., \& Sonmez, S. (1999). Exploring the touristic image of Jordan. Tourism Management, 20, 539-542. http://dx.doi.org/10.1016/S0261-5177(99)00023-0 